Article

\title{
Evaluation and Selection Methods of Tourism Characteristic Town: The Case of Liaoning Province, China
}

\author{
Fang Zhou ${ }^{1, *}$, Fei Zhao ${ }^{2}$, Qingwei $X u^{1} * \mathbb{D}$, Yongbo Yuan ${ }^{3}$ and Mingyuan Zhang ${ }^{3}$ \\ 1 College of Information and Management Science, Henan Agricultural University, Zhengzhou 450046, China \\ 2 West China Region of China Resources Land Limited, Xi'an 710000, China; zhaofei128@crland.com.cn \\ 3 Department of Construction Management, Dalian University of Technology, Dalian 116024, China; \\ yongbo@dlut.edu.cn (Y.Y.); myzhang@dlut.edu.cn (M.Z.) \\ * Correspondence: zhoufang@henau.edu.cn (F.Z.); xuqingwei@henau.edu.cn (Q.X.)
}

Received: 5 June 2020; Accepted: 29 June 2020; Published: 2 July 2020

\begin{abstract}
The construction of a characteristic town is an important measure to promote the economic transformation and upgrading of China. It also promotes the coordinated and balanced development between urban and rural areas, and the construction of new urbanization and new rural areas. At present, China's township governments are actively declaring construction projects of characteristic town. Considering the limitation of resources and funds, the government needs to choose projects with better foundation and better development prospects to invest and build, to avoid the waste of resources brought about by blind construction. Starting from the pre-selection of the construction projects of the characteristic town, taking Liaoning Province as an example, this research divided the characteristic town into four categories. Initially established the characteristic town evaluation index system blending comprehensive and multivariate index; then optimizes the index system through the statistical analysis, reliability analysis; and validity analysis of the questionnaire survey to finally obtain the selection index system of the construction projects of the characteristic town of Liaoning Province. Secondly, using the combination of Analytic Network Process (ANP) and Improved Technique for Order Preference by Similarity to an Ideal Solution (Improved-TOPSIS) method, the selection evaluation model of tourism-type characteristic town construction projects are obtained. Finally, taking the three tourism-type characteristic town projects declared by Liaoning Province as an example, using the ANP and Improved-TOPSIS evaluation model to evaluate and compare the three towns. The priority of "Xietun Town, Tanghe Town, Zhaoquanhe Town" is obtained. The result is consistent with the recommended order and verifies the applicability of the selection model. At the same time, through the feedback of the evaluation process, the current development constraints of the three towns are clarified, and the future development direction of the town is pointed out.
\end{abstract}

Keywords: characteristic town; tourism town; the selection evaluation model; ANP and improved-TOPSIS

\section{Introduction}

With China's economic development into the new normal, the simple "growthism" development model has become unsustainable, and some problems in the development process have been gradually highlighted. Recently, more attention has been paid to the imbalance of development between regions, such as the development gap between urban and rural areas, and the large income distribution gap between residents; as well as over-concentration of resources, such as industry, fund, technology, talent highly concentrating in large cities, etc. As a result of this, the Chinese government has repeatedly stressed the need to promote the coordinated development of urban and rural integration, promote 
urban and rural transformation and achieve balanced economic development. In such an era and development background, the construction projects of "characteristic town" were put forward as a new measure and a new model in 2016.

The characteristic towns that are studied in this paper include the "characteristic town" and the "characteristic small town". "Characteristic town" mainly refers to focusing on the characteristic industries and emerging industries, gathering the development elements (which is different from the administrative designated town and innovation), and entrepreneurship platforms of industrial parks. The "characteristic small town" refers to the administrative designated town with the traditional administrative division as the unit, distinct characteristic industry, a certain population, and economic scale. Both refer to gathering relevant elements, such as organizations, institutions, enterprises and personnel, and the developing a modern community with a characteristic and cultural atmosphere, based on a characteristic industry. These two forms complement each other and support each other.

The construction of characteristic towns is determined by the development status quo of China and is an important measure to promote the development of the rural economy. China has elevated the cultivation and construction of characteristic towns to a national rural development strategy. Governments at all levels have made financial support plans for the construction of characteristic towns. The construction of characteristic towns has become the most prominent carrier and presentation mode of China's new urbanization at the current stage. It can not only release part of the functions of large and medium-sized cities, but also improve the comprehensive carrying capacity of surrounding cities. On the one hand, characteristic towns start from the development of characteristic industries, tap into local characteristics, promote the enrichment and development of the industrial system, increase the employment of the rural population, and promote the development of villages and towns. On the other hand, through industrial development and economic upgrading, the characteristic town creates a living environment that is more suitable for people to live for a long time, and the spatial layout is in harmony with the ecological environment, to absorb labor and realize the revitalization of towns and villages.

With the support of the policy, the construction project of "characteristic town" has developed rapidly in China. In July 2016, Ministry of Housing and Urban-Rural Development of the People's Republic of China (MOHURD), National Development and Reform Commission (NDRC) and Ministry of Finance of the People's Republic of China (MFPRC) jointly issued the Notice on the Cultivation of Characteristic Town. The notice clearly states that by 2020 China will cultivate about 1000 small towns with unique characteristics and vitality, and lead the construction of small town [1]. In October of the same year, NDRC of China issued the Guidance on Speeding Up the Construction of Small (City) Town with Beautiful Characteristics. The guidance states the connection and distinction between the characteristic town and the characteristic small town, and puts forward the requirements and suggestions for the construction and development of the characteristic town [2]. In March 2019, NDRC of China issued the Key Tasks for the construction of the New Urbanization in 2019. The document states that we should support the orderly development of the characteristic town and adhere to the idea of characteristics thriving the town and industry constructing the town [3].

As an important development strategy in the fight against poverty, various parts of China are actively applying for characteristic towns to improve rural development. To our knowledge, few studies have yielded how the government choose "characteristic town" construction projects more reasonable planning. Better foundation and better development prospects for investment projects from a large number of declared projects to invest and build is currently the most urgent problem China's "characteristic town" construction projects face. Therefore, it is necessary to carry out relevant theoretical research on characteristic towns.

The characteristic towns studied in this paper include the characteristic town and the characteristic small town. Both refer to gathering relevant elements like organizations, institutions, enterprises and personnel and the developing a modern community with a characteristic and cultural atmosphere based on a characteristic industry. Although there is no clear concept of a characteristic town in 
foreign countries, the relationship between rural and urban areas studied by many scholars is very instructive for the development of characteristic Chinese towns. McGee et al. [4] argued that the goal of development should be to increase the links between rural and urban areas in order to generate social change, not to separate them. It is, therefore, necessary to replace the old division between rural and urban areas with urban and rural planning and to adopt sustainable management strategies to create reliable urban areas, cities and societies. Bantjes et al. [5] assessed the applicability of node development theory in small towns and rural areas and simulated the impact of density of the building environment, the distribution of amenities and related changes in travel distance to improve social facilities and environmental sustainability in small towns or rural environments. Chen et al. [6] jumped out of the traditional town planning model, introduced the panoramic viewpoint, put forward the development strategy of the characteristic town from the four levels of "full level" "full space" "all factors" "all dimensions". They put forward a specific strategy combined with the actual situation of the characteristic town of Guzhu town in Heyuan City, Guangdong Province, China.

The human society is embedded and enmeshed in economic and non-economic [7]. Local resources, population, environment and so on will affect economic development, among which the non-economic factors mentioned refer to cultural, political and other factors. Similarly, Granovetter [8] argues that social behavior is influenced by economic structure and social environment, and is intertwined with complex social relationships. Stiles and Cameron [9] discussed how rural communities in Atlantic Canada had changed their old development models, summarized lessons learned from the past development of the region's rural areas, and provided guidance on economic viability and ecological health for their future development.

Existing studies show that the development of characteristic towns can be roughly divided into economic and non-economic factors, among which economic development is the cornerstone of the development of characteristic towns. The main factors that affect the distribution of characteristic town are economic basis, population density, industrial cluster innovation, and urbanization level [10]. The construction of rural areas needs to abandon the old development ideas and drive the economic development of the region by making rational use of its unique resources. $\mathrm{Xi}$ et al. [11] built the dynamic coupling mechanism of culture source plus an industrial cluster of characteristic town, put forward the construction of characteristic town should be in line with the cultural source and industrial cluster. Saunders et al. [12] explored how small-town government personnel use the "capital-based" framework to plan sustainable development, thereby promoting the development of local society, economy, environment and culture, i.e., planning a small town that is based on their unique capital.

The non-economic factors of the characteristic town directly restrict economic development. Only by fully exploiting the local characteristics can the economic development of the surrounding area be promoted [13]. The functional system and characteristic system are the cornerstones of the formation and development of characteristic towns [14]. Li et al. [15] insisted that the development of characteristic towns should be coordinated from ecological construction, characteristic industries, urban planning and construction and cultural undertakings and many other aspects. From the point of view of embeddedness, Fu et al. [16] divided the characteristic town's embeddedness expressive style into three categories: natural resource endowment, social capital base and market demand preference. On this basis, they discussed the development model and development proposal of the characteristic town under different embedded types. Xu et al. [17] put forward the sustainable development path of the characteristic town and some suggestions for its healthy development according to local natural resources and location advantages. Jiang et al. [18] used Analytic Hierarchy Process (AHP) to build an evaluation system for the function of characteristic town tourism, including ecological value, ornamental value, social value and economic value-which in total 17 indexes from four aspects, and analyzed the index weight. Then finally, used the method of example research to analyze the cloud manufacturing town. Ma et al. [19] maintained the development of the characteristic town is significantly influenced by the local characteristic resources and culture, and the geographical type presents five categories, among which the advantages of the regional base condition of the industrial 
development-type in the plain area or agricultural service-type, river network-type or low-town historical and cultural tourism-type are significant. Xu et al. [20] considered that emphasizing traditional culture is the sustainable development road of characteristic town construction; local culture is the driving force of the construction of characteristic small town; and nonmaterial culture is the culture of characteristic towns, and it is also an important embodiment of extracting characteristics.

If the correct evaluation and selection method can be established, the blind construction can be avoided, and the waste of resources and funds can be reduced. By visiting the grass-roots towns in Liaoning Province, China, interviewing government workers, and consulting policy and declaration materials related to the characteristic town, we found that the research theory of traditional small town does not apply to the characteristic town. But at present, the choice of "characteristic town" construction projects does not have accurate and objective selection index and measure standard. Only by establishing the correct evaluation and selection method can we effectively avoid blind construction and reduce the waste of resources and funds.

In this paper, the evaluation and selection evaluation model blending comprehensive and multivariate index for the tourism-type characteristic town is established to guide the objective selection of construction projects of "characteristic towns" in China. First of all, it surveyed from the perspective of the pre-project selection, and then established an evaluation selection index system for characteristic town projects, based on the results of the research. The index system takes into account the common and individual character develop cooperatively, the division of functional areas of characteristic town, the rationality of special planning, the clarity of the support of characteristic industries, the difficulty of planning and the difficulty of realizing the planning scheme, etc. In addition, according to the results of the questionnaire survey, a selection evaluation model based on Analytic Network Process (ANP) and Improved Technique for Order Preference by Similarity to an Ideal Solution (Improved-TOPSIS) was established for the evaluation of the pre-selection of the construction projects of characteristic town. In the process of pre-selection, the systematic evaluation of the characteristic town declaration project is beneficial to find the problems in the construction scheme of each town, and put forward scientific and reasonable improvement methods.

This study provides an exciting opportunity to advance our knowledge of select the declared town construction projects. This evaluation model can help the government to judge the construction projects with more reasonable planning and better development prospects, to maximize the construction benefits. Governments can obtain relevant feedback information through evaluation results, thus, clearly restrict the main factors of the development of towns, to promote the development of towns to take into account the living facilities, environment, population, transportation and other aspects, and ultimately achieve the sustainable development of towns.

\section{The Selection Indicator for Project Evaluation in the Characteristic Town}

\subsection{Establishment Evaluation Index System}

The development of characteristic towns must be based on objective reality, scientific and reasonable planning, accurate self-consciousness, and give full play to their common social benefits. By learning the development status and the declaration process of the characteristic town, a number of characteristic towns in Liaoning Province got field visit. Through the exchange with the town government personnel, the required content information is obtained, the field information and data is grasped, and the foundation for the whole research is laid. Taking into account the construction requirements and objectives of the characteristic town, and referring to the relevant national and provincial policies, the evaluation system established in this paper includes two categories: comprehensive indicator and multivariate indicator. 


\subsubsection{Comprehensive Indicator}

The comprehensive indicators, based on economic factors, cover the economic development level of the featured towns, the development level of the featured industries, the current development level, the construction level of service facilities and the construction level of institutions and mechanisms. Consulting the relevant documents and the declaration materials of the characteristic town, the comprehensive index of 32 characteristic towns was selected from the four dimensions of the development level of the characteristic industry, the current level of development of the town, the level of construction of service facilities and the level of the construction of the institutional mechanism. A conceptual model of the selection index system for the characteristic town projects was constructed (as shown in Table 1).

Table 1. Comprehensive indicator.

\begin{tabular}{|c|c|c|}
\hline Dimension & First-Level Index & Second-Level Index \\
\hline \multirow{3}{*}{$\begin{array}{l}\text { Development level of } \\
\text { characteristic industries }\end{array}$} & Degree of product specialization & $\begin{array}{c}\text { The number of leading industrial enterprises; } \\
\text { the leading industry output value accounting for the } \\
\text { total output value. }\end{array}$ \\
\hline & Level of Scientific and technological & $\begin{array}{l}\text { Employment of people with a college education or } \\
\text { above in leading enterprises. }\end{array}$ \\
\hline & Input and output level & $\begin{array}{l}\text { Annual investment amount of leading industrial } \\
\text { enterprises; the ratio of the output value of the } \\
\text { leading industry to the annual investment amount; } \\
\text { number of employed personnel absorbed. }\end{array}$ \\
\hline \multirow{3}{*}{$\begin{array}{l}\text { The current level of } \\
\text { development of the town }\end{array}$} & Level of economic development & $\begin{array}{l}\text { GDP per head; town GDP as a proportion of the } \\
\text { county's GDP; public budget revenue; per capita net } \\
\text { income of rural residents; investment in fixed assets } \\
\text { of the whole society; the proportion of fixed asset } \\
\text { investment in the non-state-owned economy to fixed } \\
\text { asset investment. }\end{array}$ \\
\hline & Level of social development & $\begin{array}{l}\text { The area of construction land per capita; } \\
\text { the proportion of the resident population in the seat } \\
\text { of government of the town to the resident population } \\
\text { in the administrative region of town. }\end{array}$ \\
\hline & Living environment level & $\begin{array}{c}\text { Tap water hygiene compliance rate; the rate of } \\
\text { harmless disposal of household waste; standard } \\
\text { discharge rate of domestic sewage; greening } \\
\text { coverage of built-up areas. }\end{array}$ \\
\hline \multirow{2}{*}{$\begin{array}{l}\text { The level of construction of } \\
\text { service facilities }\end{array}$} & Infrastructure level & $\begin{array}{l}\text { Whether to pass the second-level or above highway; } \\
\text { the amount of parking spot; density of highways } \\
\text { network; broadband household occupancy rate; } \\
\text { Wi-Fi coverage in public areas; the number of } \\
\text { cultural and sporting venues. }\end{array}$ \\
\hline & Public service facilities & $\begin{array}{c}\text { The number of hospitals above Level } 2 \mathrm{~B} \text {; the number } \\
\text { of supermarket chains or business centers; } \\
\text { the number of branches of banks and credit unions; } \\
\text { the number of branches of express; the number of } \\
\text { hotels above three-star standard; the number of } \\
\text { primary and secondary schools within } 1 \mathrm{~km} \text { of } \\
\text { the town. }\end{array}$ \\
\hline \multirow{5}{*}{$\begin{array}{l}\text { Construction level of system } \\
\text { and mechanism }\end{array}$} & & The number of projects using Public-Private \\
\hline & Model of Investment and financing & Partnership (PPP), Build-Operate-Transfer (BOT) and \\
\hline & & $\begin{array}{l}\text { other innovative financing methods. } \\
\text { The administrative agencies and administrative }\end{array}$ \\
\hline & Government guidance level & services of the town government are set up \\
\hline & & $\begin{array}{l}\text { completely; the planning of town construction is } \\
\text { complete and multi-rule integration is realized. }\end{array}$ \\
\hline
\end{tabular}

The initial construction of the selection index system for characteristic town construction projects contains 10 first-level index under four dimensions, namely: Degree of industrial specialization, talent together with science and technology level, input generation level, economic development level, social development level, living environment level, infrastructure level, public service facilities, investment and financing model and government guidance. There are 32 secondary indexes under the first-level indexes. 


\subsubsection{Multivariate Indicator}

Some small towns in China lack their own characteristics, and there is an urgent need to solve this problem and find a way to cultivate the characteristics of small towns [21,22]. The integration of the development of the town with the local characteristic industries can promote the local economy, and it is more representative that tourism is combined with the development of the town. Parlett et al. [23] took Edinburgh Old Town as their research subject and proposed a way to assess the economic impact of tourism on the Old Town, which provided the direction for achieving and maintaining tourism-related economic growth and social vitality. Gu and Ryan [24] quantitatively studied the local impact of tourism and used structural equation models to demonstrate the far-reaching impact of tourism development on town residents, society, economy and many other aspects. Kim et al. [25] put forward a theoretical model of the perceived impact of residents in their communities on their tourism industry, surveyed more than 300 community residents, discussed the relationship among urban community construction, residents' quality of life and tourism development, and verified the enhanced effect of tourism development on the improvement of residents' well-being. From the perspective of regional tourism, Su et al. [26] excavated the tourism and community relationships, found that tourism exerts positive economic influences. Research results also support mutually supportive relations between tourism and other traditional economic activities.

Existing research recognizes the critical role played by the local characteristic industries. In addition to cultivating characteristic tourism types, we can also cultivate historical and cultural types, ethnic characteristics, modern agriculture and ecologically livable towns [27]. The Guidance on Promoting the Construction of Characteristic Townships points out that it is necessary to clarify the direction of cultivation of characteristic townships. Based on the analysis of non-economic factors in characteristic towns, comprehensively considering the economic structure of Liaoning Province and the opinions of the construction of characteristic townships in Liaoning Province, the industrial-types of the characteristic town in Liaoning Province are divided into four categories: industry, tourism, cultural and modern agriculture. According to the above four types of characteristic town, different multivariate index has been established. The multivariate indexes included in the degree of industry specialization of the first-level index, including 12 indexes under the four types of industrial-type, tourism-type, cultural-type and modern-agriculture-type characteristic town, as shown in Table 2.

Table 2. Multivariate indicators.

\begin{tabular}{cc}
\hline Categories & Multivariate Index \\
\hline Industrial-type characteristic town & $\begin{array}{c}\text { The total amount of proven mineral resources; the total } \\
\text { output value of industrial production; the high-tech } \\
\text { patent ownership } \\
\text { Tourism-type characteristic town } \\
\text { Scenic area level; the total output of tourism; The total } \\
\text { number of tourism reception. }\end{array}$ \\
Cultural-type characteristic town & $\begin{array}{c}\text { The proportion of people working in the cultural } \\
\text { industry; the number of intangible cultural heritage } \\
\text { projects at or above the provincial level; the total output } \\
\text { value of the characteristic cultural industry. } \\
\text { The total output value of agriculture, forestry, animal } \\
\text { husbandry and fisheries; the degree of production of } \\
\text { agricultural mechanization; land production rate. }\end{array}$ \\
\hline
\end{tabular}

$>$ Characteristic town of industry

The leading industries in the characteristic town of industrial-type are general and processing industries, including mineral resources processing and production. The industrial-type characteristic town can rely on traditional industry, introduce advanced technology and high-tech talent, increase research and development and investment, promote industrial progress and drive the development of towns.

$>$ Characteristic town of tourism 
Tourism-type characteristic town is a characteristic town with entertainment and tourism as the dominant industry. Tourism-type town can rely on the local superior natural environment and scenic spots, develop tourism resources, support tourism facilities, provide tourism services, but also can carry out agritainment, optimize facilities, create an ecological livable environment and attract urban people to come there for a holiday and rest, thereby driving the development of the regional economy.

\section{$>$ Characteristic town of cultural}

Cultural-type characteristics town mainly includes historical culture and national characteristic industries. Cultural type and tourism type share similarities, it regards culture as the core of the development of the industry. Tourism can be used as part of the cultural industry. Besides tourism, the cultural industry also includes art performances, souvenir processing, film and television production, books publishing and so on. It can be positioned correctly by being combined with the local cultural characteristics and build and develop the characteristics industries of national culture.

\section{$>$ Characteristic town of modern agriculture}

The leading industries of the modern-agricultural-type town are agriculture, forestry, animal husbandry and fishery production, and their related processing industries. Farmers should not be forgotten in the development of characteristic towns. The construction of agricultural-type town is essential and is an important help to promote rural development. The modern agricultural-type characteristic town can rely on local advantages, introduce high-tech and promote modern agricultural development.

\subsection{The Inspection and Analysis of the Questionnaire}

The initial establishment of the index system is only a comprehensive construction in theory; its practicality also needs to be evaluated through verifying whether the consistency within the index system has a strong correlation with the evaluation of the characteristic town, that is, whether the index is effective or not to judge [28]. Therefore, through the form of a questionnaire, this study let each respondent evaluate the degree of importance of characteristic town selection evaluation index, and collected the results of the questionnaire for credibility and validity analysis, and finally achieved the characteristic town evaluation index system verification and optimization, to make the index system more accurate.

The questionnaire designed in this paper consists of four parts: Description of the questionnaire, respondent's background, the survey of the index of importance degree, and the respondents' suggestions for the setting of the index. The questionnaire used the five-point Likert scale to evaluate the importance of 45 secondary indicators. The Likert scale usually has five or seven points, and this study uses a five-point Likert scale. A total of 110 questionnaires were distributed in the survey, 104 effective questionnaires were collected, and the effective rate of recovery was $94.5 \%$. Respondents' information is shown in Figure 1.

For the collected questionnaire data, verify the credibility and validity of the data, to judge the importance of the index and then achieve the aim of optimizing the index system. To this end, the study uses SPSS software to carry out descriptive statistical analysis, reliability analysis and validity analysis of the data. 


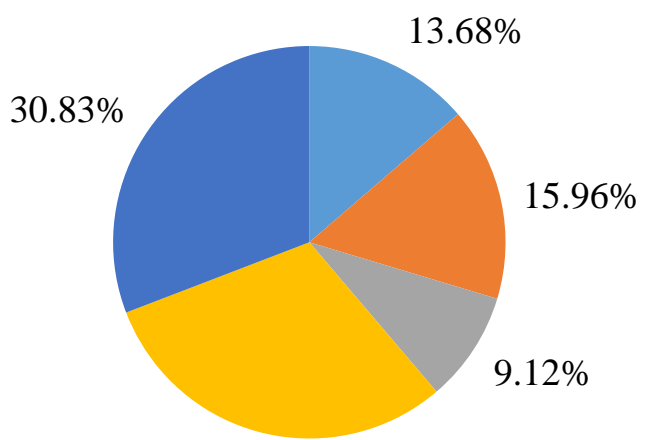

$30.40 \%$

Government

- Designing institute

- Construction company

$\square$ Colleges and universities

n Other

(a) Institution

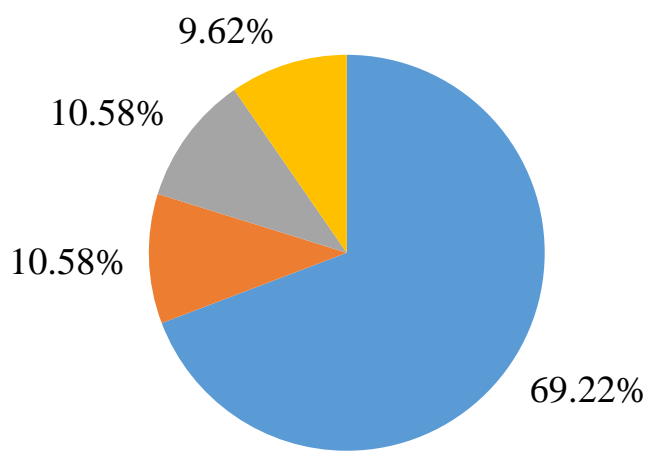

- Less than 5 years

- 6-10 years

11-15 years

More than 16 years

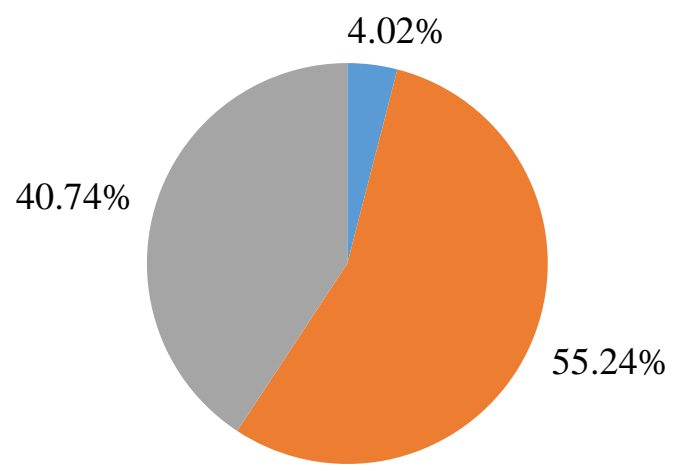

$\square$ Junior college and below

- Undergraduate

Master degree or above

(b) Education background.

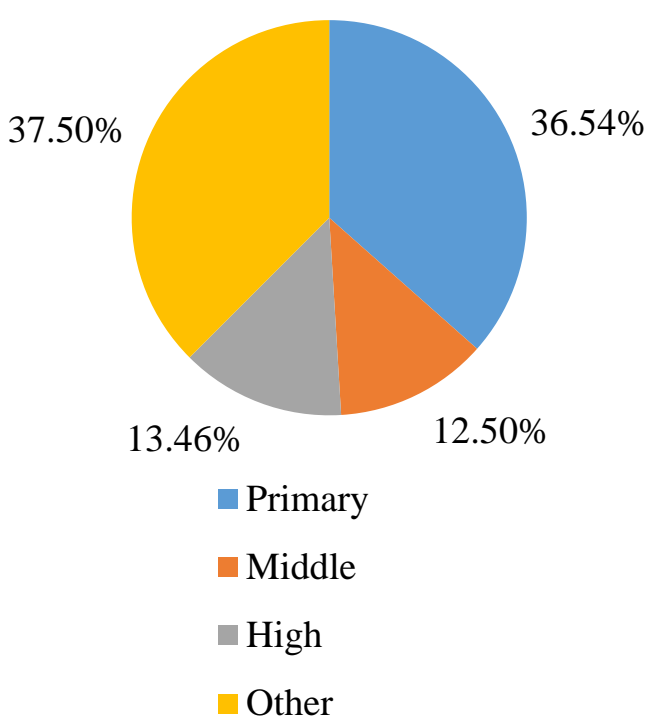

(d) Professional title

(c) Work experience

Figure 1. Statistical table of information of interviewees.

\subsubsection{Descriptive Statistical Analysis and Reliability Analysis}

Descriptive statistical analysis is the judgment and analysis of the overall situation of the questionnaire data, which describes the distribution of the questionnaire data by means of maximum, minimum, mean and standard deviation. First of all, analyze of the extreme index values: There are eight indexes of the minimum of 2; 37 indexes of the minimum of 1 ; and the maximum of all indexes are 5 , so it can be shown that the importance of the evaluation of each index is a certain difference. Secondly, analyze the standard deviation of each index, where the standard deviation of 45 indexes 
are less than 1, indicating that respondents' opinions on the same index tend to be consistent. Finally, the mean of each index is analyzed. It is found that the mean of all indexes is between 3.82-4.30; that is, the respondents generally believe that all indexes have a certain impact on the characteristic town projects preference.

The reliability reflects the stability of the data measurement results and is usually tested using Cronbach coefficient $\alpha$. In general, the closer $\alpha$ value is to 1 , the better the reliability is [29]. In this survey, the reliability of the whole questionnaire was 0.953 , indicating that the results of the questionnaire were very good and credible.

\subsubsection{Validity Test}

Validity refers to the degree the questionnaire results can reflect on things to be examined, reflecting the accuracy and effectiveness of a measurement. In this paper, the factor analysis function in SPSS software is used to test the validity of the questionnaire. Because the index contained in this questionnaire is divided into a common and characteristic index, and each type of town only has three characteristic indexes, and all reflect the development of the industry. The index attribute is obvious. Therefore, in the factor analysis, the comprehensive index is mainly analyzed, and the main component is extracted.

In the study, Kaiser-Meyer-Olkin (KMO) statistics and Bartlett spherical test are usually used to determine whether the questionnaire results can get factor analyzed. In general, when KMO is more than 0.7 and Bartlett spherical test significance probability Sig is less than 0.05 , the questionnaire results are suitable for factor analysis. Using SPSS software, the questionnaire data of comprehensive index can be selected for applicability test, the KMO value can be obtained 0.858 , which is more than 0.7, and Bartlett spherical test significance probability Sig can be obtained 0.000, which is less than 0.05 . Therefore, the questionnaire results are suitable for factor analysis.

The results of the questionnaire were input into the SPSS software to carry out factor analysis. It can be seen from the total variance of factor interpretation that a total of seven common factors whose characteristic values greater than 1 are extracted, and the cumulative variance contribution rate of the common factor is $67.588 \%$, greater than $60 \%$. It indicated that these seven public factors could summarize the total information of $67.588 \%$. Thus, the factor extraction results are ideal. The factor rotation converges after eight iterations, and the rotation factor matrix is shown in Table 3.

The value in the rotation factor matrix refers to the factor load value of the variable under a common factor. The larger the factor load value is, the more correlated the variable is with the common factor, thus, making it easier to name and interpret the common factor. In addition, the index expressing the same characteristic can be gathered under the same common factor by the factor load value of the variable on the common factor, which makes the classification of the index more obvious [30]. After factor analysis and common factor interpretation, the first-level indexes of comprehensive index can be optimization, to obtain the final reliable structure and validity index system.

\subsection{Optimization of the Evaluation Index System}

By analyzing the questionnaire data, we can find that: (1) The 33 comprehensive indexes in the initial establishment of the index system are all valid and need not be deleted; (2) There are some problems in the classification of the initial establishment of the index system, the original 10 first-level indexes are not objective and too complicated. After factor analysis and common factor interpretation, the first-level indexes can be classified into seven, which are, industrial specialization, input and output level, social and economic level, living environment level, infrastructure level, public service facilities and government guidance level.

After a series of analysis and adjustment, finally obtained the index system model which meets the requirements of better credibility. In order to facilitate the calculation of the weight of the index and the evaluation of the construction projects of the characteristic town, the index is renumbered here. The multivariate index belongs to the degree of industry specialization of the first-level index. 
However, because the multivariate index varies with the type of industry, the multivariate index of the characteristic town for each kind of industry is a number of A3, A4, A5 under the evaluation index system. This index system can be used to evaluate and select the projects created in the characteristic town.

Table 3. Rotation factor matrix.

\begin{tabular}{|c|c|c|c|c|c|c|c|}
\hline \multirow{2}{*}{ Index Name and Number } & \multicolumn{7}{|c|}{ Factor Matrix } \\
\hline & 1 & 2 & 3 & 4 & 5 & 6 & 7 \\
\hline 1. The number of leading industrial enterprises; & 0.113 & 0.110 & 0.171 & 0.066 & 0.251 & 0.849 & 0.108 \\
\hline 2. The leading industry output value accounting for the total output value & 0.142 & 0.122 & 0.056 & 0.025 & 0.265 & 0.863 & -0.054 \\
\hline 3. Employment of people with a college education or above in leading enterprises; & 0.174 & 0.051 & 0.383 & 0.033 & 0.388 & 0.323 & -0.342 \\
\hline 4. Annual investment amount of leading industrial enterprises; & 0.018 & 0.215 & 0.123 & 0.067 & 0.749 & 0.118 & 0.184 \\
\hline $\begin{array}{l}\text { 5. The ratio of the output value of the leading industry to the annual } \\
\text { investment amount: }\end{array}$ & 0.204 & 0.105 & -0.169 & 0.166 & 0.801 & 0.180 & 0.074 \\
\hline 6. Number of employed personnel absorbed & 0.212 & 0.171 & 0.192 & 0.054 & 0.742 & 0.136 & -0.239 \\
\hline 7. GDP per head; & 0.114 & 0.546 & 0.143 & 0.097 & 0.515 & 0.238 & 0.087 \\
\hline 8. Town GDP as a proportion of the county's GDP; & -0.184 & 0.688 & 0.108 & 0.099 & 0.425 & 0.139 & 0.040 \\
\hline 9. Public budget revenue; & 0.035 & 0.634 & 0.013 & 0.125 & 0.414 & 0.181 & -0.205 \\
\hline 10. Investment in fixed assets of the whole society; & 0.267 & 0.642 & 0.019 & 0.178 & 0.159 & -0.113 & 0.338 \\
\hline $\begin{array}{l}\text { 11. The proportion of fixed asset investment in non-state-owned economy to } \\
\text { fixed asset investment; }\end{array}$ & 0.251 & 0.583 & 0.127 & 0.040 & 0.168 & -0.016 & 0.124 \\
\hline 12. Per capita net income of rural residents; & 0.352 & 0.733 & 0.125 & 0.126 & 0.057 & 0.093 & -0.003 \\
\hline 13. The area of construction land per capita; & -0.014 & 0.741 & 0.150 & 0.206 & -0.047 & 0.117 & -0.075 \\
\hline $\begin{array}{l}\text { 14.The proportion of the resident population in the seat of government of the } \\
\text { town to the resident population in the administrative region of town }\end{array}$ & -0.093 & 0.433 & 0508 & 0.235 & 0.032 & 0.118 & 0.064 \\
\hline 15.Tap water hygiene compliance rate; & 0.688 & 0.081 & 0.226 & 0.220 & 0.272 & 0.003 & 0.140 \\
\hline 16.The rate of harmless disposal of household waste; & 0.840 & 0.044 & 0.165 & 0.151 & 0.209 & -0.049 & -0.023 \\
\hline 17.Standard discharge rate of domestic sewage; & 0.856 & 0.113 & 0.184 & 0.146 & 0.064 & 0.113 & 0.043 \\
\hline 18.Greening coverage of built-up areas & 0.663 & 0.149 & 0.165 & 0.281 & -0.001 & 0.309 & 0.126 \\
\hline 19.Whether to pass the second-level or above highway; & 0.524 & 0.190 & 0.263 & 0.251 & -0.017 & 0.389 & 0.023 \\
\hline 20. The amount of parking spot; & 0.311 & 0.071 & 0.520 & 0.316 & 0.258 & 0.102 & 0.145 \\
\hline 21.Density of highways network; & 0.341 & 0.196 & 0.144 & 0.511 & 0.069 & 0.179 & 0.115 \\
\hline 22. Broadband household occupancy rate; & 0.402 & -0.076 & 0.702 & 0.153 & 0.207 & -0.030 & 0.098 \\
\hline 23.Wifi coverage in public areas; & 0.186 & 0.095 & 0.788 & 0.199 & 0.076 & 0.086 & -0.019 \\
\hline 24. The number of cultural and sporting venues & 0.325 & 0.311 & 0.614 & 0.187 & -0.130 & 0.135 & 0.118 \\
\hline 25.The number of hospitals above Level $2 \mathrm{~B}$; & 0.505 & 0.288 & 0.367 & 0.304 & 0.046 & 0.234 & -0.138 \\
\hline 26.The number of supermarket chains or business centers; & 0.127 & 0.097 & 0.224 & 0.736 & 0.164 & 0.019 & 0.210 \\
\hline 27.The number of branches of banks and credit unions; & 0.206 & 0.035 & 0.153 & 0.684 & 0.225 & 0.031 & 0.114 \\
\hline 28.The number of branches of express; & 0.167 & 0.240 & 0.476 & 0.540 & 0.035 & -0.024 & -0.271 \\
\hline 29.The number of hotels above three-star standar & 0.272 & 0.160 & 0.454 & 0.562 & -0.081 & 0.221 & -0.148 \\
\hline 30.The number of primary and secondary schools within $1 \mathrm{~km}$ of the town & 0.210 & 0.421 & 0.079 & 0.702 & 0.007 & -0.059 & -0.112 \\
\hline $\begin{array}{l}\text { 31. The number of projects using PPP, BOT and other innovative } \\
\text { financing methods; }\end{array}$ & 0.148 & 0.320 & 0.403 & 0.371 & -0.062 & 0.155 & 0.336 \\
\hline $\begin{array}{l}\text { 32. The administrative agencies and administrative services of the town } \\
\text { government are set up completely; }\end{array}$ & 0.427 & 0.113 & 0.322 & 0.222 & 0.109 & 0.102 & 0.605 \\
\hline $\begin{array}{l}\text { 33. The planning of town construction is complete and multi-rule integration } \\
\text { is realized. }\end{array}$ & 0.400 & 0.311 & 0.517 & 0.061 & 0.078 & 0.239 & 0.303 \\
\hline
\end{tabular}

\section{Selection Evaluation Model}

\subsection{ANP-Based Index Weight Calculation}

After the evaluation index is determined, in order to obtain more accurate evaluation results, the weight of each index still needs to be calculated, and the weight reflects the importance of the index relative to other indexes in the evaluation process. At present, the common weight determination methods include the subjective method represented by Delphi or AHP and the objective method represented by the entropy method. In this study, the Analytic Network Process (ANP) method is used to calculate the weight value of each index.

ANP is a method formed by the further development based on AHP. AHP is to treat the problem under study as a system. In many complex system problems, the elements within the system always interact with each other, not only the domination of the upper layer over the lower layer, but there is also feedback from the upper layer to the lower layer. At this time, the whole system is no longer a hierarchical structure, but more similar to the network structure. So ANP is more suitable for this kind of problem. ANP can consider the interaction between elements and more accurately describe the relationship between objective facts, making the decision more accurate and effective. ANP makes up for the defect that the weight of AHP is too idealized, due to the assumption of independent indicators when it is used, which is the superiority and of ANP over AHP. Since the characteristic town selection 
evaluation index developed in this paper is not completely independent, there is a certain influence relationship, so the Analytic Network Process method is used to calculate the weight.

In the process of solving the index weight, this paper uses Super Decisions software that can solve the ANP network model to carry out an auxiliary calculation to solve the problem of super-matrix solving. As this paper involves four types of characteristic towns, and the selection index of four types of towns are totally different, so different types of characteristic town ANP structure model and the weight of each index are also different, so it needs classification when calculating the index weight. Considering the commonality of its calculation process, this paper introduces the calculation process of index weight only for the tourism-type town.

The steps for establishing model are as follows:

(1) Build element groups and internal elements. Create, name and describe the new element groups, and complete the establishment and naming of element nodes within each element group in turn;

(2) Establish a network relationship between elements. Since the characteristic town selection evaluation index developed in this paper is not completely independent, there is a certain influence relationship, so the ANP method is used to calculate the weight. This paper took the tourism-type town as an example, through the consulting literature, analyzing index data, understanding the meaning behind the index and discussing with the relevant researchers. We can judge and obtain the correlation of the index in the tourism-type town evaluation index system. As shown in Table 4, the first column is the parent node and the second column is the child node affected by the parent node, which can construct a complete ANP structural model. The ANP structural model for building tourism-type characteristic town is shown in Figure 2.

Table 4. The influence relationship between indicators of tourist towns.

\begin{tabular}{|c|c|}
\hline The Secondary Indicators & Affected Indicator Number \\
\hline A1.The number of leading industrial enterprises & $\mathrm{A} 4, \mathrm{~B} 1, \mathrm{~B} 2, \mathrm{~B} 4, \mathrm{C} 1, \mathrm{C} 2, \mathrm{C} 3, \mathrm{C} 5, \mathrm{C} 6, \mathrm{G} 1$ \\
\hline A2.The leading industry output value accounting for the total output value & $\mathrm{A} 1, \mathrm{~B} 1, \mathrm{~B} 2, \mathrm{~B} 4$ \\
\hline A3.Scenic spot grade & $\mathrm{A} 4, \mathrm{~A} 5, \mathrm{~B} 2, \mathrm{~B} 4$ \\
\hline A4. Total value of tourism & $\mathrm{A} 2, \mathrm{~B} 2, \mathrm{~B} 3, \mathrm{C} 1, \mathrm{C} 2, \mathrm{C} 3, \mathrm{C} 4, \mathrm{C} 5$ \\
\hline A5.Tourist reception total & $\mathrm{A} 4, \mathrm{~B} 4, \mathrm{C} 2, \mathrm{C} 3, \mathrm{C} 4, \mathrm{~F} 5$ \\
\hline B1.Employment of people with a college education or above in leading enterprises & $\mathrm{C} 1, \mathrm{C} 5, \mathrm{C} 6, \mathrm{C} 7, \mathrm{C} 8$ \\
\hline B2.Annual investment amount of leading industrial enterprises & $\mathrm{A} 4, \mathrm{~A} 5, \mathrm{~B} 3, \mathrm{C} 5, \mathrm{C} 6, \mathrm{E} 2, \mathrm{E} 5, \mathrm{~F} 5$ \\
\hline B3.The ratio of the output value of the leading industry to the annual investment amount & $\mathrm{A} 1, \mathrm{~B} 2, \mathrm{C} 5, \mathrm{C} 6$ \\
\hline B4. Number of employed personnel absorbed & $\mathrm{B} 1, \mathrm{C} 1, \mathrm{C} 5, \mathrm{C} 6, \mathrm{C} 7, \mathrm{C} 8, \mathrm{~F} 4$ \\
\hline C1. GDP per head & $\mathrm{C} 2, \mathrm{C} 4, \mathrm{C} 8, \mathrm{E} 4, \mathrm{~F} 2, \mathrm{~F} 3, \mathrm{~F} 4$ \\
\hline C2. Town GDP as a proportion of the county's GDP & $\mathrm{B} 4, \mathrm{C} 3, \mathrm{C} 5, \mathrm{C} 8, \mathrm{G} 1, \mathrm{G} 2, \mathrm{G} 3$ \\
\hline C3. Public budget revenue & $\mathrm{C} 5, \mathrm{D} 1, \mathrm{D} 2, \mathrm{D} 3, \mathrm{D} 4, \mathrm{E} 1, \mathrm{E} 3, \mathrm{E} 5, \mathrm{E} 6, \mathrm{~F} 1, \mathrm{~F} 6, \mathrm{G} 1, \mathrm{G} 2, \mathrm{G} 3$ \\
\hline C4. Per capita net income of rural residents & F4 \\
\hline C5. Investment in fixed assets of the whole society & $\mathrm{D} 1, \mathrm{D} 2, \mathrm{D} 3, \mathrm{E} 3, \mathrm{E} 5, \mathrm{E} 6, \mathrm{~F} 1, \mathrm{~F} 6$ \\
\hline \multicolumn{2}{|l|}{$\begin{array}{l}\text { C6.The proportion of fixed asset investment in the non-state-owned economy to fixed } \\
\text { asset investment }\end{array}$} \\
\hline C7. The area of construction land per capita & $\mathrm{D} 4, \mathrm{E} 2, \mathrm{E} 3, \mathrm{E} 6, \mathrm{~F} 1, \mathrm{~F} 2, \mathrm{~F} 3, \mathrm{~F} 5, \mathrm{~F} 6$ \\
\hline \multicolumn{2}{|l|}{$\begin{array}{l}\text { C8. The proportion of the resident population in the seat of government of the town to the } \\
\text { resident population in the administrative region of town }\end{array}$} \\
\hline D1. Tap water hygiene compliance rate & $\mathrm{A} 3, \mathrm{~B} 1, \mathrm{~B} 4, \mathrm{C} 8$ \\
\hline D2. The rate of harmless disposal of household waste & $\mathrm{A} 3, \mathrm{~B} 1, \mathrm{~B} 4, \mathrm{C} 8$ \\
\hline D3. Standard discharge rate of domestic sewage & $\mathrm{A} 3, \mathrm{~B} 1, \mathrm{~B} 4, \mathrm{C} 8$ \\
\hline D4. Greening coverage of built-up areas & $\mathrm{A} 3, \mathrm{~B} 1, \mathrm{~B} 4, \mathrm{C} 7, \mathrm{C} 8$ \\
\hline E1. Whether to pass the second-level or above highway & $\mathrm{A} 3, \mathrm{~A} 4, \mathrm{~A} 5, \mathrm{E} 3$ \\
\hline E2. The amount of parking spot & A3 \\
\hline E3. Density of highways network & $\mathrm{A} 3, \mathrm{~A} 4, \mathrm{~A} 5, \mathrm{~B} 4, \mathrm{C} 1$ \\
\hline \multicolumn{2}{|l|}{ E4. Broadband household occupancy rate } \\
\hline \multicolumn{2}{|l|}{ E5. Wi-Fi coverage in public areas } \\
\hline E6. The number of cultural and sporting venues & $\mathrm{C} 5, \mathrm{C} 7, \mathrm{C} 8$ \\
\hline F1. The number of hospitals above Level $2 \mathrm{~B}$ & $\mathrm{~B} 1, \mathrm{~B} 4, \mathrm{C} 3, \mathrm{C} 7, \mathrm{C} 8$ \\
\hline F2. The number of supermarket chains or business centers & $\mathrm{B} 1, \mathrm{~B} 4, \mathrm{C} 3, \mathrm{C} 7, \mathrm{C} 8$ \\
\hline F3. The number of branches of banks and credit unions & $\mathrm{B} 1, \mathrm{~B} 4, \mathrm{C} 3, \mathrm{C} 7, \mathrm{C} 8$ \\
\hline \multicolumn{2}{|l|}{ F4. The number of branches of express } \\
\hline F5. The number of hotels above three-star standard & $\mathrm{A} 4, \mathrm{~A} 5, \mathrm{~B} 1, \mathrm{~B} 4, \mathrm{C} 3, \mathrm{C} 7, \mathrm{C} 8$ \\
\hline F6. The number of primary and secondary schools within $1 \mathrm{~km}$ of the town & $\mathrm{B} 1, \mathrm{~B} 4, \mathrm{C} 3, \mathrm{C} 7, \mathrm{C} 8$ \\
\hline \multicolumn{2}{|l|}{ G1. The number of projects using PPP, BOT and other innovative financing methods } \\
\hline $\begin{array}{l}\text { G2. The administrative agencies and administrative services of the town government are } \\
\text { set up completely }\end{array}$ & $\mathrm{A} 1, \mathrm{G} 1, \mathrm{G} 3$ \\
\hline G3. The planning of town construction is complete and multi-rule integration is realized & $\mathrm{B} 2, \mathrm{~B} 4, \mathrm{C} 5, \mathrm{C} 6, \mathrm{C} 7, \mathrm{E} 1, \mathrm{E} 2, \mathrm{E} 3, \mathrm{E} 6, \mathrm{~F} 1, \mathrm{~F} 6$ \\
\hline
\end{tabular}




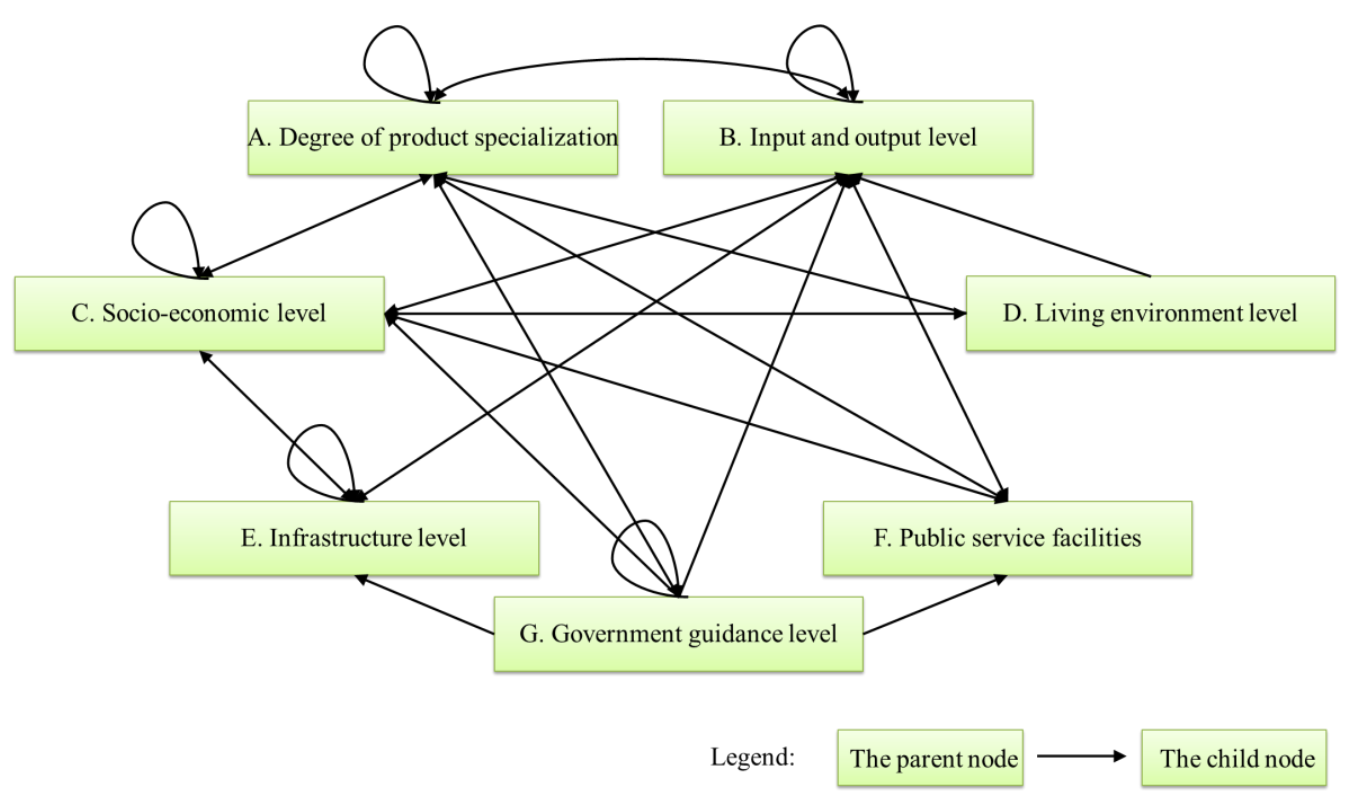

Figure 2. Analytic Network Process (ANP) structure model of a tourist town.

(3) Build an unweighted super-matrix. According to the principle of the dominance of ANP, using 1-9 scaling method, 10 experts (who have studied the policy and development of characteristic towns in-depth) evaluated and scored the relative importance of each index, thus, forming a judgment matrix. The backgrounds of the ten experts are shown in Table 5.

Table 5. The expert backgrounds.

\begin{tabular}{|c|c|c|c|c|}
\hline No. & Institution & Position & Relevant Work Experience & Number of Respondents \\
\hline 1 & $\begin{array}{l}\text { Institute of Planning } \\
\text { and Design }\end{array}$ & Senior Researcher & $\begin{array}{l}\text { Characteristic town } \\
\text { planning experience }\end{array}$ & 2 \\
\hline 2 & $\begin{array}{l}\text { Cushman and } \\
\text { Wakefield }\end{array}$ & Adviser Consultant & $\begin{array}{l}\text { Characteristic town consulting } \\
\text { project experience }\end{array}$ & 2 \\
\hline 3 & Government & Civil Servant & $\begin{array}{l}\text { The government executive of the } \\
\text { characteristic town }\end{array}$ & 2 \\
\hline 4 & Construction company & Engineer & $\begin{array}{l}\text { Once participated in the construction } \\
\text { process of characteristic town }\end{array}$ & 2 \\
\hline 5 & $\begin{array}{l}\text { Colleges } \\
\text { and Universities }\end{array}$ & Professor & $\begin{array}{l}\text { Participated in relevant research } \\
\text { projects of characteristic towns }\end{array}$ & 2 \\
\hline
\end{tabular}

Then, all the data for the two comparisons between the element groups under the different criteria layers and the different elements under the same element group are input, so that an unweighted super-matrix can be obtained, and the weights are calculated on this basis.

(4) Build element group weight matrix and weighted super-matrix. In order to get the importance of the index elements relative to the decision target, that is, the unweighted super-matrix of the whole is normalized, so the element group weight matrix and weighted super-matrix need to be constructed. Whether the consistency test results are less than 0.1 , if less than 0.1 , the consistency test is passed, and a weighted super-matrix is obtained.

(5) Limit super-matrix. In order to correctly reflect the interdependence between indexes, it is necessary to make the weighted super-matrix stabilize through continuous iteration. Then obtain the normalized characteristic vector of each element, and finally get the limit super-matrix $W^{\infty}$.

(6) Determine the element weight. Only one decision target and element groups and elements at the network layer, considering less multiple decision-making criteria in the characteristic town index system. Calculate the priority of each element group and element under the decision target without to repeat the above steps to weight the network layer elements under the different criteria layer, just. Therefore, we can get the weight results of each element relative to the target layer. 
Repeat this step for the 10 expert questionnaire data. Exclude two data that failed the consistency test and normalize the weight values obtained from the remaining 8 data, and the index weights of tourism-type towns were eventually obtained, as shown in Table 6.

Table 6. The index weight of tourism town.

\begin{tabular}{|c|c|c|c|}
\hline Dimension & First-Level Index & Second-Level Index & Weight \\
\hline \multirow{9}{*}{$\begin{array}{l}\text { Development level of } \\
\text { characteristic industries }\end{array}$} & \multirow{5}{*}{$\begin{array}{l}\text { A. Degree of } \\
\text { product specialization }\end{array}$} & A1. The number of leading industrial enterprises; & 0.02138 \\
\hline & & $\begin{array}{l}\text { A2. The leading industry output value accounting for the total } \\
\text { output value; }\end{array}$ & 0.01669 \\
\hline & & A3. Scenic spot grade; & 0.02353 \\
\hline & & A4. Total value of tourism; & 0.03392 \\
\hline & & A5. Tourist reception total; & 0.01806 \\
\hline & \multirow{4}{*}{ B. Input and output level } & $\begin{array}{l}\text { B1. Employment of people with a college education or above } \\
\text { in leading enterprises; }\end{array}$ & 0.08414 \\
\hline & & $\begin{array}{l}\text { B2. Annual investment amount of leading } \\
\text { industrial enterprises; }\end{array}$ & 0.02867 \\
\hline & & $\begin{array}{l}\text { B3. The ratio of the output value of the leading industry to the } \\
\text { annual investment amount; }\end{array}$ & 0.01418 \\
\hline & & B4. Number of employed personnel absorbed; & 0.08565 \\
\hline \multirow{12}{*}{$\begin{array}{l}\text { The current level of } \\
\text { development of the town }\end{array}$} & \multirow{8}{*}{ C. Social and economic level } & C1. GDP per head; & 0.06269 \\
\hline & & C2. Town GDP as a proportion of the county's GDP; & 0.00908 \\
\hline & & C3. Public budget revenue; & 0.04272 \\
\hline & & C4. Per capita net income of rural residents; & 0.01917 \\
\hline & & C5. Investment in fixed assets of the whole society; & 0.06885 \\
\hline & & $\begin{array}{l}\text { C6. The proportion of fixed asset investment in the } \\
\text { non-state-owned economy to fixed asset investment; }\end{array}$ & 0.02163 \\
\hline & & C7. The area of construction land per capita; & 0.02882 \\
\hline & & $\begin{array}{l}\text { C8. The proportion of the resident population in the seat of } \\
\text { government of the town to the resident population in the } \\
\text { administrative region of town; }\end{array}$ & 0.07004 \\
\hline & \multirow{4}{*}{ D. Living environment level } & D1. Tap water hygiene compliance rate; & 0.01348 \\
\hline & & D2. The rate of harmless disposal of household waste; & 0.00817 \\
\hline & & D3. Standard discharge rate of domestic sewage; & 0.01131 \\
\hline & & D4. Greening coverage of built-up areas; & 0.00812 \\
\hline \multirow{12}{*}{$\begin{array}{l}\text { The level of construction } \\
\text { of service facilities }\end{array}$} & \multirow{6}{*}{ E. Infrastructure level } & E1. Whether to pass the second-level or above highway; & 0.00252 \\
\hline & & E2. The amount of parking spot; & 0.00426 \\
\hline & & E3. Density of highways network; & 0.03372 \\
\hline & & E4. Broadband household occupancy rate; & 0.0276 \\
\hline & & E5. Wi-Fi coverage in public areas; & 0.01159 \\
\hline & & E6. The number of cultural and sporting venues; & 0.01181 \\
\hline & \multirow{6}{*}{ F. Public service facilities } & F1. The number of hospitals above Level $2 \mathrm{~B}$; & 0.04109 \\
\hline & & F2. The number of supermarket chains or business centers; & 0.01533 \\
\hline & & F3. The number of branches of banks and credit unions; & 0.02139 \\
\hline & & F4. The number of branches of express; & 0.08337 \\
\hline & & F5. The number of hotels above three-star standard; & 0.01642 \\
\hline & & $\begin{array}{l}\text { F6. The number of primary and secondary schools within } 1 \\
\mathrm{~km} \text { of the town; }\end{array}$ & 0.02454 \\
\hline \multirow{3}{*}{$\begin{array}{l}\text { Construction level of } \\
\text { system and mechanism }\end{array}$} & \multirow{3}{*}{ G. Government guidance level } & $\begin{array}{l}\text { G1. The number of projects using PPP, BOT and other } \\
\text { innovative financing methods; }\end{array}$ & 0.00814 \\
\hline & & $\begin{array}{l}\text { G2. The administrative agencies and administrative services } \\
\text { of the town government are set up completely; }\end{array}$ & 0.00284 \\
\hline & & $\begin{array}{l}\text { G3. The planning of town construction is complete and } \\
\text { multi-rule integration is realized; }\end{array}$ & 0.00509 \\
\hline
\end{tabular}

\subsection{Selection Evaluation Based on Improved-TOPSIS}

In this paper, the evaluation model of Technique for Order Preference by Similarity to an Ideal Solution (TOPSIS) is used to select the construction projects of characteristic town. The TOPSIS method, also known as the Technique for Order Preference by Similarity to Ideal Solution, is sorted by calculating the relative distance between each evaluation object and the calculated ideal optimal solution (positive ideal solution) and ideal worst solution (negative ideal solution). In Euclidean space, the closer the distance to the positive ideal solution and the further the distance from the negative ideal solution is, the better the scheme is. In order to avoid the phenomenon of reverse order in the practical application of the TOPSIS method, this paper introduces the Improved-TOPSIS evaluation model. By setting the absolute positive ideal solution and absolute negative ideal solution ensure that the change of the scheme number will not change the ideal solution. 
Within the effective scope involved in the decision-making, no one scheme will be better than the absolute positive ideal solution, nor worse than the absolute negative ideal solution. When the number of scheme is increased or decreased, nothing of the absolute ideal solution will change. Therefore, the advantages and disadvantages relationship of each evaluation object related to the absolute ideal solution remains unchanged, thus, eliminating the reverse order of the traditional TOPSIS model.

In the selection evaluation of the characteristic town projects, the first step is to determine the type of industry of the characteristic town, and then put the characteristic town of the same type of industry together for comparison and selection. The specific selection evaluation characteristic town steps are as follows:

Step 1: Collect data, calculate each index attribute value for each alternative project, and construct the initial decision matrix;

Step 2: Standardize the original index value of each scheme, and before the comprehensive comparison of the scheme, the data of the original decision matrix should be standardized, to obtain the normalized decision matrix:

$$
y_{i j}=\frac{x_{i j}}{\sqrt{\sum_{i=1}^{m} x_{i j}^{2}}}(i=1,2, \ldots, \mathrm{m} ; j=1,2, \ldots, \mathrm{n})
$$

Step 3: Determine the unweighted absolute positive ideal solution as $Y_{1 \times n}^{+}=(1,1, \ldots, 1)$, and the absolute negative ideal solution as $Y_{1 \times n}^{-}=(0,0, \ldots, 0)$;

Step 4: Select the index weight value under the corresponding industry type according to the index weight, weight the standardized data processing, and determine the absolute ideal solution of the weighting:

$$
Z^{+}=\left(z_{1}^{+}, z_{2}^{+}, \cdots, z_{n}^{+}\right) ; Z^{-}=\left(z_{1}^{-}, z_{2}^{-}, \cdots, z_{n}^{-}\right)
$$

where $z_{j}^{+}=\max _{i} z_{i j}, j \in J_{1} ; \min _{i} z_{i j}, j \in J_{2} ; z_{j}^{-}=\min _{i} z_{i j}, j \in J_{1} ; \max _{i} z_{i j}, j \in J_{2}$;

Step 5: Calculate the Euclidean distance of each scheme to the absolute positive ideal solution $D_{i}^{+}$ and to the absolute negative ideal solution $D_{i}^{-}$:

$$
\begin{aligned}
& D_{i}^{+}=\sqrt{\sum_{j=1}^{n}\left(z_{i j}-z_{j}^{+}\right)^{2}},(i=1,2, \ldots, \mathrm{m}) \\
& D_{i}^{-}=\sqrt{\sum_{j=1}^{n}\left(z_{i j}-z_{j}^{-}\right)^{2}},(i=1,2, \ldots, \mathrm{m})
\end{aligned}
$$

Step 6: Based on the formula (5), calculate the relative closeness of each alternative project to the ideal solution $C_{i}$ and the higher the $C_{i}$, the better the scheme is, according to the size of the $C_{i}$ value:

$$
C_{i}=\frac{D_{i}^{-}}{D_{i}^{+}+D_{i}^{-}},(i=1,2, \ldots, \mathrm{m})
$$

Step 7: After the traditional TOPSIS method is standardized in data processing, the values in the normalized decision matrix are between 0 and 1 , that is, the maximum value obtained after standardization of the original values of all indexes is 1 , and the minimum value obtained is 0 . The characteristic town evaluation index established in this paper is benefit type index. Therefore, the absolute positive ideal solution corresponding to the standardization of the data is $Y_{1 \times n}^{+}=(1,1, \ldots, 1)$, the absolute negative ideal solution is $Y_{1 \times n}^{-}=(0,0, \ldots, 0)$. Think about the weight value of each index, and then we can get the weighted absolute positive ideal solution and weighted absolute negative ideal solution, respectively, is formula (6) and formula (7). This is based 
on $Z_{1 \times n}^{+}$and $Z_{1 \times n}^{-}$to calculate the Euclidean distance and relative closeness, and then to obtain the scheme's order of merit.

$$
\begin{gathered}
Z_{1 \times n}^{+}=\left(\omega_{j} y_{j}^{+}\right)_{1 \times n}=\left(\omega_{1}, \omega_{2}, \cdots, \omega_{n}\right) \\
Z_{1 \times n}^{-}=\left(\omega_{j} y_{j}^{-}\right)_{1 \times n}=(0,0, \ldots, 0)
\end{gathered}
$$

\title{
4. Case Study of Characteristic Town in Liaoning Province, China
}

\subsection{Case Background}

In this paper, three of the first batch of national-level characteristic towns, Xietun Town, Tanghe Town and Zhaoquanhe Town in Liaoning Province, were selected as research objects. The investment priorities of the town were arranged by using ANP and Improved-TOPSIS selection evaluation model. The economic situation and town situation of Liaoning Province are the basis of the whole study. By consulting the statistical yearbook data, we can obtain the added value of various industries in Liaoning Province in 2016, as well as the added value of each industry as a percentage of the GDP of Liaoning Province, as shown in Figure 3.

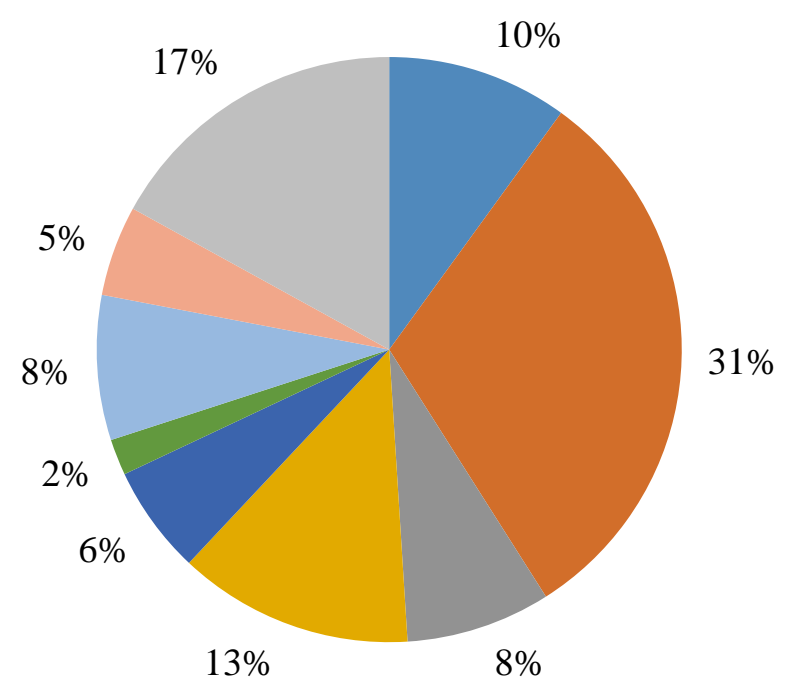

\author{
- Agriculture \\ - Industry \\ - Construction industry \\ - Wholesale and snack \\ - Transportation, storage, postal services \\ - Residential and catering \\ $\square$ Banking \\ Construction and Real Estate \\ Other
}

Figure 3. The added value of each industry as a percentage of the GDP of Liaoning. Source: Compiled by the authors based on data from the National Bureau of Statistics of China [31].

We can analyze according to Figure 3: First, Liaoning Province is still dominated by the development of the industrial economy, and the proportion of industry to the regional GDP of Liaoning Province reached more than $30 \%$. Second, the wholesale and retail trade to Liaoning Province's economic contribution ratio is in the second place, its proportion reached $13 \%$, wholesale and retail is simply the activities of goods trading circulation. This industry and people's lives are closely bound up and covered a wide range, so its proportion is larger. Third, the added value of agriculture, forestry, animal husbandry and fishery industry in Liaoning Province accounts for $10 \%$ of the region's GDP, which is located in the third place in various industries, indicating that the primary industry in Liaoning Province is the economic focus, mainly due to the unique geographical advantages of Liaoning Province and its vigorous development of agriculture and promoting the modernization of agricultural construction in recent years. Fourth, the information economy, finance and other industries of Liaoning Province lag relatively backward, so it is difficult to develop the characteristic town directly.

\subsection{Introduction of Characteristic Town in Liaoning Province}

Xietun Town, Tanghe Town, and Zhaoquanhe Town are the first batches of national-level characteristic towns, and the leading types of the three towns are essentially the same, which are all 
dominated by tourism, driving the development of other related industries. The relative value such as the area of the administrative region of town and a resident population of the three towns are shown in Figure 4.

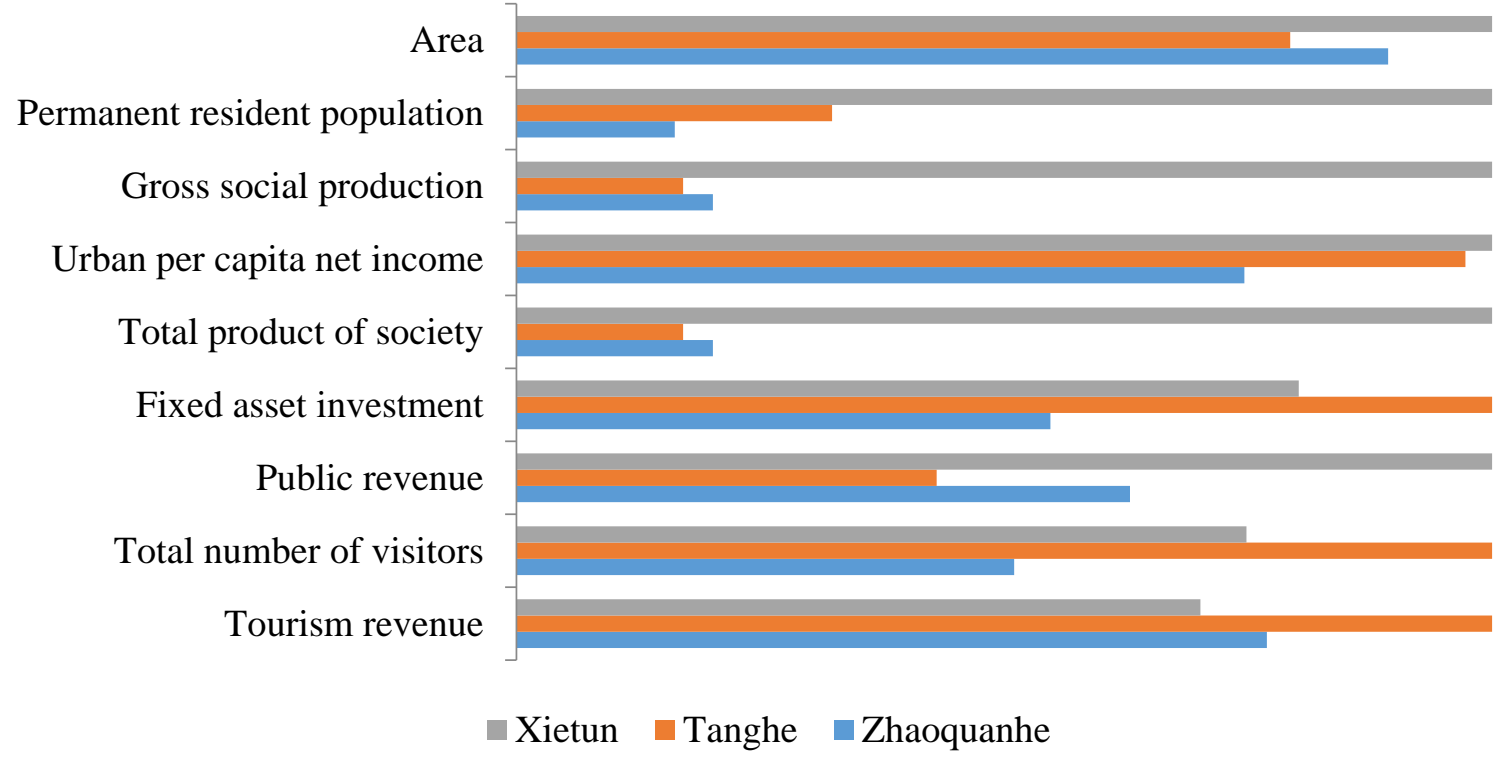

Figure 4. Basic parameters of towns. Source: Compiled by the authors based on data from the declaration materials for national characteristic towns.

\subsubsection{Xietun Town}

Xietun Town is located in the north of Dalian City and the southwest of Wa Fangdian City, $50 \mathrm{~km}$ from downtown Wa Fangdian City. The town's road network is perfect, and transportation is convenient. In terms of infrastructure, Xietun town currently has a central water plant, and the villages under the jurisdiction have also built a water supply network. The town's tap water penetration rate has reached $96 \%$. In terms of public services, the town has a central hospital, primary and secondary school teaching buildings, gerocomium, comprehensive cultural stations, etc. to meet the needs of the people's lives. After years of development, Xietun Town has gradually formed leisure tourism, old-age care, fisheries, facilities agriculture, sea salt industry, wine industry and other industries, of which leisure tourism, old-age industry development have become the leading industry in Xietun Town. Xietun town has been identified as a characteristic town of leisure tourism and old-age industry, and constructs and improves the town's infrastructure and public service facilities, which made the town radiate and drove a larger regional scope to promote the development and construction of its surrounding villages and towns.

\subsubsection{Tanghe Town}

Tanghe Town is located in the southeast of Liaoyang City. The town location conditions are first-class, transportation is convenient, and the town can effectively undertake the radiation and drive of every city in Shenyang Economic Zone. At the same time, Tanghe Town has abundant reserves, domestic rare weakly alkaline high temperature medical radon spring and metasilicic acid type natural soft mineral drinking spring. Relying on the unique advantages of hot spring resources, the town vigorously develops the hot spring tourism industry, while driving the development of related industries including snow and ice vacation, health care industry, exhibition industry, leisure agriculture, etc. Through the driving development of the hot spring tourism industry, Tanghe Town has formed a variety of "hot spring plus" combination development model, which has become one of the most influential hot spring tourism industry clusters in Northeast China, and Tanghe Town has been identified as a hot spring tourism-type town. 


\subsubsection{Zhaoquanhe Town}

Zhaoquanhe Town is located in the southwest of Panjin City, located in the core area of the Liaohe Estuary National Nature Reserve, and is an important node in the coastal economic belt of Liaoning Province. Zhaoquanhe Town has abundant eco-tourism resources. A large area of suaeda grass growing on the beach on both sides of the mouth of the Liao River estuary, the color of suaeda grass stretching for hundreds of miles will become more and more intense with the changes of the seasons, forming a unique "red beach" landscape. In addition, Zhaoquanhe Town has the best-preserved and largest wetland resources in the world, which is an important part of the Liaohe Estuary wetland. There are rich geothermal hot spring resources, marine water, and freshwater aquaculture resources. Therefore, Zhaoquanhe Town is identified as a tourism-type characteristic town.

\subsection{Evaluation of Characteristic Town Based on ANP and Improved-TOPSIS Model}

By contacting with the government workers in three towns, relative data of the three towns were obtained for 2015. After the data were calculated and processed, the index values for the three tourism-type towns were obtained, as shown in Table 7.

Table 7. The original values of the towns.

\begin{tabular}{|c|c|c|c|c|}
\hline Index & Units & Xietun & Tanghe & Zhaoquanhe \\
\hline A1. The number of leading industrial enterprises & Pieces & 24 & 426 & 81 \\
\hline $\begin{array}{l}\text { A2. The leading industry output value accounting for } \\
\text { the total output value }\end{array}$ & $\%$ & $9.45 \%$ & $78.88 \%$ & $51.63 \%$ \\
\hline A3. Scenic spot grade & A grade & 4 & 4 & 4 \\
\hline A4. Total value of tourism & $1000 ¥$ & 638284 & 910000 & 700000 \\
\hline A5. Tourist reception total & Thousands of people & 220 & 294 & 150 \\
\hline $\begin{array}{l}\text { B1. Employment of people with a college education or } \\
\text { above in leading enterprises }\end{array}$ & People & 856 & 381 & 1195 \\
\hline $\begin{array}{l}\text { B2. Annual investment amount of leading } \\
\text { industrial enterprises }\end{array}$ & $1000 ¥$ & 2000000 & 1797460 & 965500 \\
\hline $\begin{array}{l}\text { B3. The ratio of the output value of the leading industry } \\
\text { to the annual investment amount }\end{array}$ & $\%$ & $31.91 \%$ & $50.63 \%$ & $72.50 \%$ \\
\hline B4. Number of employed personnel absorbed & People & 4411 & 5436 & 2657 \\
\hline C1. GDP per head & $1000 ¥$ & 134.5 & 71.1 & 166.5 \\
\hline C2. Town GDP as a proportion of the county's GDP & $\%$ & $7.86 \%$ & $17.73 \%$ & $5.38 \%$ \\
\hline C3. Public budget revenue & $1000 ¥$ & 155420 & 66950 & 97760 \\
\hline C4. Per capita net income of rural residents & $¥$ & 19030 & 12036 & 16010 \\
\hline C5. Investment in fixed assets of the whole society & $1000 ¥$ & 1773000 & 2211460 & 1213100 \\
\hline $\begin{array}{l}\text { C6. The proportion of fixed asset investment in the } \\
\text { non-state-owned economy to fixed asset investment }\end{array}$ & $\%$ & $52.06 \%$ & $83.67 \%$ & $70.79 \%$ \\
\hline C7. The area of construction land per capita & $\mathrm{m}^{2}$ & 70.31 & 433.75 & 330 \\
\hline $\begin{array}{l}\text { C8. The proportion of the resident population in the seat } \\
\text { of government of town to the resident population in the } \\
\text { administrative region of town }\end{array}$ & $\%$ & $71.14 \%$ & $64.13 \%$ & $76.28 \%$ \\
\hline D1. Tap water hygiene compliance rate & $\%$ & $100 \%$ & $100 \%$ & $100 \%$ \\
\hline D2. The rate of harmless disposal of household waste & $\%$ & $95 \%$ & $100 \%$ & $100 \%$ \\
\hline D3. Standard discharge rate of domestic sewage & $\%$ & $96.50 \%$ & $81 \%$ & $100 \%$ \\
\hline D4. Greening coverage of built-up areas & $\%$ & $16.00 \%$ & $42.50 \%$ & $40.72 \%$ \\
\hline E1. Whether to pass the second-level or above highway & Yes/No & 1 & 1 & 1 \\
\hline E2. The amount of parking spot & Pieces & 1700 & 6613 & 5670 \\
\hline E3. Density of highways network & $\begin{array}{l}\text { Hundred square } \\
\text { kilometers }\end{array}$ & 95.32 & 90.37 & 88.02 \\
\hline E4. Broadband household occupancy rate & $\%$ & $35 \%$ & $95 \%$ & $56 \%$ \\
\hline E5. Wi-Fi coverage in public areas & $\%$ & $100 \%$ & $100 \%$ & $100 \%$ \\
\hline E6. The number of cultural and sporting venues & Pieces & 17 & 14 & 13 \\
\hline F1. The number of hospitals above Level $2 \mathrm{~B}$ & Pieces & 1 & 0 & 0 \\
\hline $\begin{array}{l}\text { F2. The number of supermarket chains or } \\
\text { business centers }\end{array}$ & Pieces & 9 & 4 & 13 \\
\hline F3. The number of branches of banks and credit unions & Pieces & 4 & 10 & 2 \\
\hline F4. The number of branches of express & Pieces & 8 & 15 & 13 \\
\hline F5. The number of hotels above three-star standard & Pieces & 17 & 8 & 5 \\
\hline $\begin{array}{l}\text { F6. The number of primary and secondary schools } \\
\text { within } 1 \mathrm{~km} \text { of the town }\end{array}$ & Pieces & 2 & 3 & 2 \\
\hline $\begin{array}{l}\text { G1. The number of projects using PPP, BOT and other } \\
\text { innovative financing methods }\end{array}$ & Pieces & 0 & 7 & 3 \\
\hline $\begin{array}{l}\text { G2. The administrative agencies and administrative } \\
\text { services of the town government are set up completely }\end{array}$ & Yes/No & 1 & 1 & 1 \\
\hline $\begin{array}{l}\text { G3. The planning of town construction is complete and } \\
\text { multi-rule integration is realized }\end{array}$ & Yes/No & 1 & 1 & 1 \\
\hline
\end{tabular}


There are two points need to be stated:

(1) The leading industrial output value refers to the town's tourism output value, and the total output value refers to each town's GDP in 2015; if there are many scenic areas in the town, its scenic level is based on the highest scenic level. The per capita GDP value is equal to the ratio of the town's GDP to the resident population of the town; the public budget revenue includes the fiscal revenue of the same level and the subsidies from the superiors; and the proportion of fixed asset investment in the non-state-owned economy to the fixed asset investment refers to the ratio of the amount of investment in fixed assets of the private sector to the fixed asset investment of the whole society.

(2) There are three qualitative indexes in the indexes, E1, G2 and G3, which need to be translated into quantitative indexes before evaluation. For E1, if the town already has highway above second-level, its indicator value is 1 , if not, is 0 . For G2, if the town has comprehensive law enforcement agencies, "one-stop" integrated administrative services, planning and construction management agencies and granted rural planning permission, the index value is 1 . If any of these is lacking, then deduct 0.25 . If all of these are lacking, then 0. For G3, if the town has complete and relevant planning of the construction of the characteristic town, then its index value is 1 ; otherwise it is 0 . According to the specific and actual situation of the three towns, the three indexes are converted into quantitative values.

According to the selection evaluation model of tourism-type characteristic town based on ANP and Improved-TOPSIS model, the Xietun Town, Tanghe Town and Zhaoquanhe Town were compared and evaluated. First, according to formula (1), standardize the original data processing; and secondly, according to the index weight of Table 6, weight the standardized processing of the index data and absolute ideal solution.

Use formula (3) and formula (4) to calculate the Euclidean distance of each scheme to the absolute positive ideal solution $D_{i}^{+}$and the Euclidean distance to the absolute negative ideal solution $D_{i}^{-}$, and use formula (5) to calculate the relative closeness of each scheme to the absolute ideal solution $C_{i}$, the calculation result is shown in Table 8.

Table 8. Euclid distance and relative closeness.

\begin{tabular}{cccc}
\hline Town & $\boldsymbol{D}_{\boldsymbol{i}}^{+}$ & $\boldsymbol{D}_{\boldsymbol{i}}^{-}$ & $\boldsymbol{C}_{\boldsymbol{i}}$ \\
\hline Xietun & 0.10503 & 0.12538 & 0.5442 \\
Tanghe & 0.11046 & 0.12993 & 0.5405 \\
Zhaoquanhe & 0.10973 & 0.12528 & 0.5331 \\
\hline
\end{tabular}

As can be seen from Table 8, the $C_{i}$ value of the three towns is: Xietun Town, Tanghe Town, Zhaoquanhe Town, so in the declaration projects of these three characteristic towns, Xietun Town is the best, followed by Tanghe Town, and finally Zhaoquanhe Town. Therefore, the characteristic town evaluation results based on using ANP and Improved-TOPSIS model are consistent with the recommended order of the town published by the country. This model can achieve the selection evaluation of the characteristic town projects.

Through the above selection evaluation process to form feedback, the future development of the three towns can be given a certain guide as follows:

(1) The number of leading industrial enterprises in Xietun Town and the greening coverage rate of built-up areas are obviously low. First of all, the development direction of Xietun Town is to increase investment attracting. Relevant policies and financial support can be given to enterprises to attract enterprises to settle in, thereby promoting the rapid development of leading industries. Secondly, we should vigorously build the town environment, plant multi-level green planting, increase the coverage of greening, and improve the living environment of residents.

(2) Tanghe Town's college education and employment, the standard discharge rate of domestic sewage and other indexes are low, so the future development of Tanghe Town is to focus on the introduction of talent. The government can attract talents through policies such as providing talent subsidies or subsidized housing and innovate, reform and develop through the leading industrial model 
of highly educated people. Secondly, attention should be paid to construct the living environment, improve the infrastructure, and attract people to live in.

(3) Zhaoquanhe Town's tourism reception total, leading industrial enterprises annual investment amount, the number of employment personnel and other indexes are obviously low. Therefore, attention should be paid to the publicity of tourist attractions in future development. We can consider using the Internet platform to improve the visibility of scenic spots. At the same time, Zhaoquanhe Town needs to increase investment in scenic construction, while driving the surrounding residents to employment.

\section{Conclusions}

A characteristic town is an important means to promote the coordinated development of urban and rural integration. Constructing a characteristic town in the area with a better foundation provides a new way of thinking and mode for the development of small towns, and injects vitality into the traditional industrial upgrading and the development of traditional culture. The characteristic town has four obvious features, namely, special and strong industry, gathered and convergent function, small and beauty form, new and live mechanism. These four features determine that it is different from other development subjects, but also determine that the construction of characteristic town is of great significance. With a construction boom launched across the country, governments at all levels have issued their own characteristic town construction plans, and give the characteristic town policies and funds of strong support.

In the process of promoting the construction of characteristic town, we must take into account the regional differences and the actual conditions of the town. We must also choose the area with better basic conditions to carry out the construction of characteristic town, to drive the economic development of the surrounding area more quickly and realize the return of funds. Carrying out the construction of characteristic town blindly, it will waste a lot of resources. By analyzing policy documents and questionnaires, this study established an evaluation index system for characteristic town and a selection evaluation model based on ANP and Improved-TOPSIS for the pre-selection of tourism-type characteristic town projects. For towns with general basic conditions, the main work of the government should be put on laying the foundations, not only improving the environment, protecting the history and culture, but also investing funds to improve infrastructure, and laying a solid foundation for the later development of the towns.

The characteristic town projects should be evaluated accordingly in the process of pre-selection, medium-term construction and late-stage development. The evaluation of the pre-selection is to select a more suitable area for construction investment; the medium-term construction evaluation is to judge the situation of town construction, whether to achieve the construction objectives and requirements, whether the investment planning and other aspects are in line with the policy provisions, which is the annual assessment of the characteristic town; the late-stage evaluation is to judge whether there is a greater development of the characteristic industry, to judge the efforts of characteristic town to drive the economic development of the surrounding area and to sum up the shortcomings in the construction process of the town, to avoid the same problem in the later town construction.

The establishment process of characteristic town is the process of dynamic development. In the development process of characteristic town, the evaluation index system is not changeless, but constantly changing. Therefore, we can develop index systems of different stages, thus, making the evaluation more scientific and more reasonable. In addition, the developing emphasis on different industry types of characteristic towns is also different. Therefore, different evaluation index systems should be used to evaluate different types of industrial towns. The evaluation system of the characteristic town established in this study is only suitable for the pre-selection of the characteristic town projects. However, the evaluation of the characteristic town could not be completed at one time, but needs to be dynamically evaluated according to the development progress of the characteristic town. Furthermore, Building Information Modeling (BIM) implements the evolution of traditional design, 
which incorporates geometric, costs, environmental and maintenance information [32], as well as to encourage the use of sustainable and recycled materials in the characteristic town construction [33]. Therefore, the index system used to evaluate the development status and development level of characteristic town can be adjusted dynamically with the construction of characteristic towns on the basis of the index system established in this paper. For example, the original leading industrial output value can be adjusted to the added value of the industry, and the number of employed persons can be adjusted to the number of increased jobs, etc. Thus, a complete set of index system throughout the construction of characteristic town is formed, and the sustained and healthy development of characteristic towns is promoted.

Author Contributions: F.Z. (Fang Zhou), F.Z. (Fei Zhao) and Y.Y. collaboratively worked on the theoretical framework. F.Z. (Fang Zhou) wrote the paper and outlined the research design of the study. F.Z. (Fei Zhao) collected data at the study site and did the data analysis. Y.Y. and M.Z. provided policy inputs to the paper. F.Z. (Fang Zhou) and Q.X. revised the paper. All authors have read and agreed to the published version of the manuscript.

Funding: This research received no external funding.

Acknowledgments: Thanks for the relevant government agencies of Liaoning Province, Dalian City, Xietun Town, Tanghe Town and Zhaoquanhe Town for the support of this study. Thanks for the respondents who participated in the survey. The authors thank the editor and anonymous reviewers for their valuable comments and suggestions.

Conflicts of Interest: The authors declare no conflict of interest.

\section{References}

1. Ministry of Housing and Urban-Rural Development of the People's Republic of China; National Development and Reform Commission; Ministry of Finance of the People's Republic of China. The Notice on the Cultivation of Characteristic Town; MOHURD: Beijing, China, 2016.

2. National Development and Reform Commission. The Guidance on Speeding Up the Construction of Small (City) Town with Beautiful Characteristics; Development and Reform Plan (2016) No. 2125; National Development and Reform Commission: Beijing, China, 2016.

3. National Development and Reform Commission. The Key Tasks for the Construction of the New Urbanization in 2019; Development and Reform Plan 2019 No. 617; National Development and Reform Commission: Beijing, China, 2019.

4. McGee, T.G. Managing the rural-urban transformation in East Asia in the 21st century. Sustain. Sci. 2008, 3, 155-167. [CrossRef]

5. Bantjes, R. Rural sustainability and the built environment. J. Enterp. Commun. People Places Glob. Econ. 2011, 5, 158-178. [CrossRef]

6. Chen, K.; Feng, X.; Zhuo, X. Characteristic Town Master Plan of Guzhu Town in Heyuan City of Guangdong Province from Panoramic Viewpoint. Areal Res. Dev. 2019, 38, 76-80.

7. Polanyi, K. The economy as instituted process. In Economic Anthropology; LeClair, E., Schneider, H., Eds.; Holt, Rinehart and Winston: New York, NY, USA, 1968.

8. Granovetter, M. Economic action and social structure: The problem of embeddedness. Am. J. Soc. 1985, 91, 481-510. [CrossRef]

9. Stiles, D.; Cameron, G. Changing paradigms? Rural communities, agriculture, and corporate and civic models of development in Atlantic Canada. J. Enterp. Commun. People Places Glob. Econ. 2009, 3, 341-354.

10. Xie, H.; Li, Y.; Wei, Y. Influencing Factors and Spatial Distribution of the Characteristic Towns in Zhejiang Province. Sci. Geogr. Sin. 2018, 38, 1283-1291.

11. Xi, L.; Liu, J.; Wang, M. Cultural Source plus Industrial Cluster: The Driving Force and Mechanism of the Development of Characteristic Towns in the New Era. Urban Dev. Stud. 2018, 25, c27-c31.

12. Saunders, C.; Dalziel, P. Local planning for sustainable development: A small rural district case study from New Zealand. J. Enterp. Commun. People Places Glob. Econ. 2010, 4, 252-267. [CrossRef]

13. Wu, Y.; Chen, Y.; Deng, X.; Hui, E.C. Development of characteristic towns in China. Habitat Int. 2018, 77, 21-31. [CrossRef] 
14. Li, C.; Wang, D.; Sun, F. Preliminary study on the construction methods of characteristic small towns in Qingdao-Taking Jimo hot spring small towns as example. J. Qingdao Univ. Technol. 2018, 39, 49-55.

15. Li, Z.; Zhou, B.; Zhang, M. Discussion and Analysis of the Characteristic Development of Small Town. J. Anhui Agric. Sci. 2006, 34, 3512-3514.

16. Fu, X.; Jiang, Y. Discussion on the Development Model of Characteristic Towns in China from the Perspective of Embeddedness. China Soft Sci. 2017, 8, 102-111.

17. Xu, W.; Zhang, H. Research on the Development of Global Tourism in Characteristic Towns from the Perspective of Regional Economy Taking Qingdao West Coast Characteristic Town as an Example. Sci. Technol. Dev. 2018, 14, 506-510.

18. Jiang, T. Construction of tourism function evaluation system on characteristic towns in zhejiang province. Chin. J. Agric. Resour. Reg. Plan. 2019, 40, 227-232.

19. Ma, R.; Zhou, X.; Li, Q. Regional Types of the Characteristic Towns and Its Adaptive Path in the Yangtze River Delta Region. Sci. Geogr. Sin. 2019, 39, 912-919.

20. $\mathrm{Xu}, \mathrm{M}$. Discussion on the Construction Background, Connotation and Key Points of Characteristic Towns. In Proceedings of the 2nd ICMIBI International Conference on Applied Social Science and Business, Belgrade, Serbia, 7-8 July 2017; Volume 77, pp. 69-72.

21. Wu, S.; Li, H.; Liu, G. Designing of Small Town Based on its Characteristics. Adv. Mater. Res. 2012, 450, 1053-1056. [CrossRef]

22. Zou, Y.; Zhao, W. Searching for a new dynamic of industrialization and urbanization: Anatomy of China's characteristic town program. Urban Geogr. 2018, 39, 1060-1069. [CrossRef]

23. Parlett, G.; Fletcher, J.; Cooper, C. The impact of tourism on the Old Town of Edinburgh. Tour. Manag. 1995, 16, 355-360. [CrossRef]

24. Gu, H.; Ryan, C. Place attachment, identity and community impacts of tourism-The case of a Beijing hutong. Tour. Manag. 2008, 29, 637-647. [CrossRef]

25. Kim, K.; Uysal, M.; Sirgy, M.J. How does tourism in a community impact the quality of life of community residents? Tour. Manag. 2013, 36, 527-540. [CrossRef]

26. Su, M.M.; Wall, G.; Wang, Y.; Jin, M. Livelihood sustainability in a rural tourism destination-Hetu Town, Anhui Province, China. Tour. Manag. 2019, 71, 272-281. [CrossRef]

27. The People's Government of Liaoning Province. The Guidance on Promoting the Construction of Characteristic Townships; The People's Government of Liaoning Province: Shenyang, China, 2016.

28. Da, K. Research on Core Competitive Force and Comprehensive Evaluation of Small Towns; Northeastern University: Boston, MA, USA, 2009.

29. Zhao, H. Research on Social Benefits Evaluation of the Characteristic Town in Our Country Based on SEM; Shandong Jianzhu University: Jinan, China, 2017.

30. Liu, Y.; Yuan, C.; Duan, B. SPSS 10.0 Software Statistical Analysis and Application; National Defence Industry Press: Berlin, Germany, 2002.

31. National Bureau of Statistics of China. National Data - 2016 of Liaoning Province. 2017. Available online: http://data.stats.gov.cn/easyquery.htm?cn=E0103\&zb=A0201\&reg=210000\&sj=2016 (accessed on 2 July 2020).

32. Pomares, J.C.; Baeza, F.J.; Varona, F.B.; Bru, D. BIM implementation for structural design courses in civil engineering. WIT Trans. Built Environ. 2017, 169, 79-86.

33. Pomares, J.C.; Gonzalez, A.; Saura, P. Simple and resistant construction built with concrete voussoirs for developing countries. J. Constr. Eng. Manag. 2018, 144, 04018076.1-04018076.10. [CrossRef]

(C) 2020 by the authors. Licensee MDPI, Basel, Switzerland. This article is an open access article distributed under the terms and conditions of the Creative Commons Attribution (CC BY) license (http://creativecommons.org/licenses/by/4.0/). 